\title{
Barriers of Innovation Activity as Risk Factors on the Real Estate Market
}

\author{
Marcin SITEK
}

\author{
Czestochowa University of Technology, Czestochowa, Poland \\ marcin.sitek@wz.pcz.pl
}

Received date:22 February 2019; Accepted date: 7 May 2019; Published date: 19 July 2019

Academic Editor: Laurentiu Droj

Copyright (C) 2019. Marcin SITEK. Distributed under Creative Commons CC-BY 4.0

\begin{abstract}
Innovation is the basic factor and driving force behind the company's development. The aim of the study is to identify and assess innovation barriers in the construction sector in Poland, which are risk factors of the analyzed real estate market. It has been hypothesized that the implementation of innovation on the real estate market allows better management of investments in innovations and, above all, minimizes their risk. In the light of signals of ecological imbalance caused by very intensive and irresponsible economic growth, the analysis of the problem was inspired by actions aimed to eliminate harmful impacts of human activity on the environment and promote implementation of innovations - the concept of sustainable development. For the purpose of the work purpose, surveys were used to assess the sustainable development of the real estate market in the light of benefits and threats. The work also used the literature on innovation, secondary research results, empirical data in this area, CSO data, McKinsey survey on key actions to ensure further effective development of the economy. The methodology adopted at work made it possible to present the assessment of the local real estate market implemented with innovations on the background of Poland and the UE. It has been shown that barriers to innovations are perceived as risk-generating, being an important determinant of management in the real estate market. In order to continue sustainable development in line with the EU directive, an appropriate risk management strategy should be adopted to minimize it. The work presents the concepts of innovation in the management strategy, stressing that the strategy for creating value is the most promising in the implementation of sustainable development, while providing a long-term reduction of costs.
\end{abstract}

Keywords: innovations in the real estate market, the risk of innovation implementation, sustainable development, sustainable construction.

\section{Introduction}

According to P.F. Drucker (1992)

"...Innovation is a specific entrepreneurial tool, an activity that gives resources new opportunities to generate wealth.... A noninnovative business is inevitably ageing and declining". Innovations are becoming

Cite this Article as: Marcin SITEK (2019)," Barriers of Innovation Activity as Risk Factors on the Real Estate Market", IBIMA Business Review, Vol. 2019 (2019), Article ID 870062, DOI: 10.5171/2019.870062 
increasingly important from the standpoint of the competitiveness of the economy.

For this policy, the framework for the EU was provided mainly by the Treaty of Lisbon, continued by the EUROPE 2020 Strategy (KOM (2010) 2020). On the basis of Poland, the framework of the new regional and spatial policy is determined by: Krajowa Strategia Rozwoju Regionalnego 2010-2020: Regiony, Miasta, Obszary Wiejskie (Ministerstwo 2011) oraz Koncepcja Przestrzennego Zagospodarowania Kraju 2030 (Ministerstwo 2012).

Since the transformation of the political system in Poland, construction and the real estate market have changed significantly. Real estate management as an area with a large impact on environmental pollution, in the European Union alone, it produces 10\% of GDP (Czarnecki et al. 2012), employing $7 \%$ of the EU's workforce. European buildings consume $42 \%$ energy and produce $35 \%$ greenhouse gases in the entire EU. Over $50 \%$ of materials extracted from the earth (after processing) is used in the construction sector. However, according to Wiley et al. (2010) only US buildings are responsible for using $36 \%$ of energy, $30 \%$ of greenhouse gases, use of $30 \%$ raw materials, production of $30 \%$ of waste and consumption of $12 \%$ of drinking water.

Therefore, taking into account the above and bearing in mind that nowadays the number of threats and the degree of uncertainty concerning the global development of the economy in 2018, especially the real estate market and its sustainable development, are increasing, it should be stated that construction and real estate management, as its continuation, have a huge impact on the sustainable development of the real estate sector in the environmental aspect (Sitek 2016).

The aim of the study is to identify and assess barriers to innovativeness in the construction sector. The study hypothesized that the development of the construction sector, implemented with innovations represents a necessary component of leading the economy towards sustainable development.

\section{Short Overview of Innovations}

A characteristic feature of innovative activities, which represents one of its major barriers in enterprises, is uncertainty about the final outcomes and necessity to incur considerable expenditures (Świtalski, 2005; Pudło, 2012). However, in the contemporary economy, innovative activity represents a prerequisite for improved competitiveness of enterprises and effective meeting of the needs of recipients of products and services. Therefore, based on the literature (Pomykalski, 2001; Hult, et al., 2004; Calanton, et al., 2002; Jin et al., 2004), innovativeness can be considered as a key success driver that determines competitive advantage of enterprises in the market.

Information about the benefits of innovations and the risks associated with innovations and marketing opportunities represents valuable information about the threats and opportunities that the enterprises face. They help quickly and efficiently plan preventive activities on both strategic and operating levels.

Among the innovations in the real estate market, one can distinguish innovations in the construction sector (according to the Division of Economic Activities in Poland PKD section F 48) and especially in services as real estate market service (according to PKD section L 68).

Innovation groups by field of activity (Prystom 2012) can be presented as follows:

- main innovations (Peres 2010), i.e. technical and technological innovations, including modern solutions - innovations used in construction activities (design, project implementation, operation, sustainable construction, passive houses, lofts, new building materials),

- process innovations (Jaikumar 1986) energy-efficient windows, gas condensing technology, galvanic cells, photovoltaics, 
heat pumps - recuperation, and organizational innovations (Lee et al., 2012) as ESCROW agent - in the group of innovations of organizational processes or financing mezzanine. They are connected with implementation of technological innovations, legal changes and their adjustment to the needs and requirements of the contemporary customers in the real estate market.

- marketing innovations. They concern the sales and distribution of products and services in the real estate market and involve networking and new methods of presentation of real estate offers, the use of the Internet and drones.

- financial innovation. They allow entities in the real estate market to start investments through application of modern financial instruments based on the real estate market (derivatives, covered bonds, reverse mortgage, energy-efficient mortgage, bancassurance, and new insurance products, dedicated to specific entities in the real estate market).

Table 1 presents the percentage of enterprises that introduced innovations in relation to the number of industrial and service companies in the years 2013-2017 in total and depending on the innovation groups, and expenditures on innovative activity.

As can be seen from the analysis of the information contained in GUS Reports and in the data presented in Table 1, both industrial companies and service providers showed innovative activity, where in both cases in the period 2013-2017, it increased by 1.3 percentage points. New or improved products or processes were introduced by $18.9 \%$ of industrial enterprises and $13.6 \%$ of service enterprises. As results from the presented data, in industrial enterprises and service providers, process innovations were more often introduced than product innovations. Over the analyzed years, the share of innovative enterprises implementing process innovations in the industry increased by about $22 \%$, while in the service sector, by about $14 \%$. The low level of product innovations implemented on a market scale is worrying. With a very small percentage of innovative industrial companies in Poland, this means that the chances of the industry to compete with modern products at home or abroad are low.

Table 1: Expenditures on innovative activity and percentage of innovative enterprises in Poland in 2013-2017

\begin{tabular}{|c|c|c|c|c|c|c|}
\hline \multirow{2}{*}{$\begin{array}{l}\text { Innov } \\
\text { ative } \\
\text { enter- } \\
\text { prises } \\
\text { year }\end{array}$} & \multirow{2}{*}{$\begin{array}{l}\text { Expendi- } \\
\text { tures } \\
\text { in PLN } \\
\text { million }\end{array}$} & \multirow{2}{*}{$\begin{array}{c}\text { Inno- } \\
\text { vations } \\
\text { in total } \\
\qquad \%\end{array}$} & \multicolumn{4}{|c|}{ Companies that have implemented } \\
\hline & & & $\begin{array}{l}\text { Product } \\
\text { Innovations } \\
\% \\
\end{array}$ & $\begin{array}{l}\text { Process } \\
\text { innovation } \\
\text { s } \\
\quad \%\end{array}$ & $\begin{array}{l}\text { Organi- } \\
\text { zational } \\
\text { innova } \\
\text { tions \% }\end{array}$ & $\begin{array}{l}\text { Marke- } \\
\text { ting } \\
\text { inno } \\
\text { vations } \\
\quad \% \\
\end{array}$ \\
\hline \multicolumn{7}{|c|}{ Industrial enterprises which are innovatively active } \\
\hline 2015 & 31094,1 & 18,9 & 11,$8 ; 6,49^{*}$ & 13,0 & 8,1 & 7,1 \\
\hline 2016 & 28304,7 & 20,3 & 12,$4 ; 6,3^{*}$ & 15,2 & 9,5 & 9,2 \\
\hline 2017 & 28023,5 & 20,2 & 12,$0 ; 7,1^{*}$ & 15,3 & 8,4 & 7,5 \\
\hline \multicolumn{7}{|c|}{ Service providers Innovatively active } \\
\hline 2015 & 12640,9 & 13,6 & 4,$8 ; 2,28^{*}$ & 7,4 & 8,1 & 6,6 \\
\hline 2016 & 10706,2 & 14,5 & 6,$9 ; 3,1^{*}$ & 10,4 & 7,6 & 7,2 \\
\hline 2017 & 13142,2 & 11,9 & 5,$4 ; 3,0^{*}$ & 8,3 & 7,0 & 6,9 \\
\hline
\end{tabular}

A similar situation occurs in the case of innovative service providers implementing product innovations. Only half of them offer new solutions on a market scale. The 
situation is even more difficult as there are few innovative enterprises in this sector [Janasz et al. 2017].

A number of studies to date have shown that the innovativeness of Polish enterprises, assessed based on indicators used for their measurement, has for years been lower than the level recorded in most
EU countries. This is confirmed by various studies and reports, one of the most important of which is the European Innovation Scoreboard (2017). The total innovativeness index for Poland in 2017 was at the level of 54.8, whereas the mean index for EU countries (28) amounted to 102 (see table 2).

Table 2: Indices of innovativeness and competitiveness for Poland in 2012-2018

\begin{tabular}{|l|l|l|l|l|l|l|}
\hline \multicolumn{1}{|c|}{ Years } & $2012-13$ & $2013-14$ & $2014-15$ & $2015-16$ & $\begin{array}{l}2016- \\
17\end{array}$ & $2017-18$ \\
\hline Innovativeness EU 28 & 99.2 & 100.3 & 99.2 & 100.7 & 102.0 & - \\
\hline Innovativeness index & 50.9 & 51.4 & 50.9 & 52.2 & 54.8 & - \\
\hline $\begin{array}{l}\text { Ranking of } \\
\text { competitiveness }\end{array}$ & $41 / 144$ & $42 / 148$ & $43 / 144$ & $41 / 140$ & $36 / 138$ & $39 / 137$ \\
\hline $\begin{array}{l}\text { Index of } \\
\text { competitiveness (0-7) }\end{array}$ & 4.5 & 4.5 & 4.5 & 4.5 & 4.56 & 4.59 \\
\hline
\end{tabular}

Source: own processing, data extracted from Schwab (2017-2018, pp.240-241), European (2017)

As illustrated in the table, the innovativeness index showed a slight upward trend in 2012-2017. Both the index and the position in the competitiveness ranking (in \%) showed stagnation of growth (Gorzeń-Mitka 2018; Sipa2017; Skibiński 2018). The analysis of the condition and situation of Polish enterprises in terms of innovativeness reveals that although since the beginning of the transformation the country has significantly reduced the distance to Western Europe, innovativeness is the key to the success of enterprises and entire economies in the modern world. It should become the strategic goal of the Polish economy.

\section{Methodology}

The data used to achieve the study aim and support the adopted thesis were derived from the results of the survey conducted among the entities operating in the local real estate market of Czestochowa, Poland. They were dedicated to developers and entities operating in 16 enterprises in the local market in 2017. The study size was 50 people. The respondents assessed innovative activities of the enterprises they work for, construction costs and risk limitation. Furthermore, they evaluated real barriers and benefits resulting from this type of building in the local market.

The work also uses secondary (existing) information about the real estate market, using the Desk Research analysis method. The reasons for the use of the previously published information (secondary data) were the need for the diagnosis of the formation of factors affecting the condition of the construction sector related to the implementation of innovations. DESK RESEARCH is an tool where the secondary data sources can answer specific research problems, which may not only an introduction to research, their support, but also the main source of information and data. The analysis of the existing data (statistical data of the CSO and Eurostat, reports from previous research, materials from conferences and publications), concerned innovative activity of enterprises on the real estate market, its effects as well as innovation and competitiveness indicators in the context of the assessment of the development of the real estate market in Poland was assumed.

Using the results of own research and secondary information, conclusions were formulated on the statement that the development of construction implemented 
by innovations, as a result of growing competitiveness on world markets as a result of rapid technological progress, is the main determinant of introducing the economy on the path of sustainable development.

The methodology adopted at work made it possible to demonstrate that barriers to innovation are perceived as risky, constituting an important determinant of investment management in the real estate market.
Innovations from the Standpoint of Real Estate Market Participants: Analysis of Empirical Research

The increase in the importance of innovations in the economic processes is also noticeable in the contemporary real estate market, which substantially utilizes innovative solutions used by both entities and parties of transactions in this sector. Analysis of secondary data concerning indices of innovative activity of enterprises operating in the national market, their contribution, implementations and innovative activity, especially in the construction sector and services for the real estate market are presented in table 3 .

Table 3: Results of the study obtained in the project of support for cohesion policy in the financial of 2007-2013 and 2014-2020 (Polish market)

\begin{tabular}{|l|c|c|c|}
\hline \multirow{2}{*}{ Activity of microenterprises } & \multicolumn{1}{c|}{$\begin{array}{c}\text { Innovations } \\
\text { in (\%) }\end{array}$} & \multicolumn{2}{c|}{$\begin{array}{c}\text { Activity according to the Division } \\
\text { of Economic Activities (PKD) (\%) }\end{array}$} \\
\cline { 2 - 4 } & $\begin{array}{c}\text { Contribution and } \\
\text { Implementation }\end{array}$ & $\begin{array}{c}\text { Section F-the con } \\
\text { struction sector }\end{array}$ & $\begin{array}{c}\text { Section L- } \\
\text { service }\end{array}$ \\
\hline Product innovations & 18,5 & 16.4 & 11.7 \\
\hline Orgamizational innovations & 19,9 & 18.3 & 17.6 \\
\hline Organizational innovations & 20,8 & 17.0 & 15.6 \\
\hline Earketing innovations & 10,4 & 10.0 & 11.0 \\
\hline \multicolumn{2}{|c|}{ Effects of implementation of innovations in micro-enterprises } \\
\hline
\end{tabular}

Source: Own study based on the data from GUS (2007-2013), National Cohesion Strategy (2007-2013, 20142020)

The results of the study showed that product, process and organizational innovations in the national market were implemented in the period of 2007-2020 by ca. $20 \%$ enterprises, whereas marketing innovations were implemented by only $10.4 \%$ enterprises. For the real estate market, this activity is presented according to the PKD (\%) sections (Korombel, Ławińska 2018).
The share of revenues on sales of new or significantly improved products implemented in the market in 2007-2020 in the construction sector was $2.7 \%$, whereas in the activities connected with the real estate market - only $1.8 \%$. Furthermore, innovative activity of enterprises in the construction sector and services for real estate market indicates a relatively intensive activity in the real estate market, which is manifested in the 
effects of their implementation in this market.

An analysis of the situation on the local real estate market in Czestochowa in 2016 regarding the supply of flats, housing offer by area and number of rooms, transaction prices and rental prices of flats shows that the local market, which is very small compared to the national market, with very small housing resources compared to the national market but unused opportunities for economic development, is a market with potential that is conducive to competitiveness (Urząd Statystyczny 2017; PAP 2017). But initial qualitative analysis of the local real estate market did not allow for evaluation of the perspectives of the development of sustainable housing investments. Therefore, it was used only as an inspiration for collecting the qualitative data concerning this market.

The qualitative data concerning the innovative activity on the real estate market, barriers and the risk of its implementation, as well as their analysis, obtained from research at the end of 2016, indicated the need to develop a real estate management strategy in line with sustainable development in order to minimize risk. Survey data on innovative activities differed between entrepreneurs, especially depending on the enterprise size.
In small enterprises, respondents opted for implementation of innovations, with major motivations being the improvement in competitive position of the enterprise, increase in its reputation, development of the enterprise, finding new customers and financial benefits. When asked about future benefits of innovations, the respondents emphasized development of the enterprise, improved competitiveness and enhanced brand recognition. They also stressed the importance and types of innovations implemented in the enterprises and listed them according to the order of importance as technologies, products and services. The respondents demonstrated good knowledge concerning public and private support to innovative activities and emphasized complex procedures used to obtain support, insufficient capitals and human and physical resources. These factors also represent barriers to implementation of innovations. Analysis of the survey concerning implementation of innovations in the local real estate market demonstrated benefits and barriers to innovations as a key determinant of the concept of competitiveness and balance development. The main benefits of introducing innovations and barriers to their perception by enterprises in Poland in the local, national and the EU 28 market are presented in table 4 .

Table 4. Barriers and the main benefits of sustainable-innovative

construction [\%] (2016 r.)

\begin{tabular}{|l|c|c|c|}
\hline \multicolumn{1}{|c|}{ Problem } & $\begin{array}{l}\text { Local } \\
\text { market }\end{array}$ & National market & EU \\
28 & \\
\hline \multicolumn{2}{|c|}{ Barriers according to market participants of the real estate market } \\
\hline $\begin{array}{l}\text { Low demand for innovative products and } \\
\text { service }\end{array}$ & 28 & 49 & 28 \\
\hline Poor distribution channels & 2 & 52 & 36 \\
\hline Lack of marketing knowledge & 6 & 45 & 39 \\
\hline Market dominated by major competitors & & 78 & 65 \\
\hline $\begin{array}{l}\text { Difficulties in maintaining the intellectual } \\
\text { property laws }\end{array}$ & & 32 & 21 \\
\hline Administrative and legal problems & 12 & 62 & 46 \\
\hline Finding and using new technologies & 2 & 41 & 33 \\
\hline No human resources & 6 & 60 & 46 \\
\hline Lack of financial funds & 50 & 74 & 60 \\
\hline
\end{tabular}




\begin{tabular}{|l|c|c|c|}
\hline \multicolumn{4}{|c|}{ The main benefits } \\
\hline Reduced operating cost (energy and water) & 54 & 99 & \\
\hline Reduced operating cost of long-term use & 40 & 80 & \\
\hline No impact on the environment & 43 & 78 & \\
\hline Certificate as an advantage & 20 & 75 & \\
\hline Reduced design and construction costs & 50 & 76 & \\
\hline Lowering the investment risk & 28 & 57 & \\
\hline $\begin{array}{l}\text { Technology development using raw materials } \\
\text { secondary and ecological }\end{array}$ & 20 & 66 & \\
\hline
\end{tabular}

Source: Own study based on the survey data (Sitek 2018) and the dates from Construction (2015) and European $(2016,2017)$

As can be seen from table 4 , in the case of benefit analysis, the assessment of sustainable construction through the local market in the context of the domestic market has indicated that the main priorities of the construction industry are similar for both markets, as reduced operating costs, no environmental impact, maintenance costs, design and construction and the importance of pro-ecological activities. Minor differences in the importance of successive benefits are due in particular to the underdeveloped local market, in the context of the domestic market. However, the analysis of barriers shows that deficiency of financial funds, lack of human resources, administrative and legal problems and the biggest barrier (dominance of leading competitors in the market) remain to be the major challenges. Therefore, it can be concluded that the state of Poland's innovativeness determines the state's competitive position in the indirect manner, pointing how far is the country behind the leader. Furthermore, the barriers to perceiving innovations in Poland (table 4, barriers $1,3,7,9$ ) with respect to the real estate market point to the sustainable construction, which the European Commission indicated as one of the six lead market initiatives susceptible to innovations (SITEK, 2016).

In addition, the analysis of barriers detailed both for the local real estate market, as well as domestic, clearly supports the fact that barriers are one of the risk factors of the analyzed market. In order to continue sustainable development in accordance with the EU Directive, it is necessary to take such actions that are economically valuable, and at the same time socially responsible, environmentally friendly and minimizing the risk.

The main benefits of the implementation of innovations into the local market are reduced operating costs, no effect on the environment, costs of maintenance, design and construction, and the importance of environmental initiatives. The lack of financial funds and human resources, administrative and legal problems, and the biggest barrier (dominance of leading competitors in the market) remain to be the major concerns. Therefore, the state of Poland's innovativeness determines the state's competitive position in the indirect manner, pointing how far is the country behind the leader.

The secondary data used in the analysis of innovations and innovative risk, such as data published by PAP (2017), GUS (20072013), McKinsey (2015), European Innovation Scoreboard (European 2016) and author's own study demonstrated, that one of the key tasks is investments in innovativeness of the economy. Furthermore, the report of European Innovation Scoreboard 2016 demonstrated that one of the strengths of Poland is human resources and investments of the enterprises for whom innovativeness represents a key activity to ensure a fast development of the Polish economy.

The presented data suggest that in the case of the real estate market, the market risk connected with innovative activities is considered as medium since technical, 
technological and organizational successes of innovative activity are connected with the increasing innovative success of the product in the market.

\section{Innovativeness in the Company Management Strategy: Creating Value}

Nowadays, economic and social transformations, progressing globalization and unification of the market force modern company management, where the most frequently used management concepts are oriented towards the process of company management, concepts concerning change management or oriented towards forms of organization. According to Grudzewski (2006) this is:

- organization to management process: marketing, logistics, humanization of labor and teamwork orientation, comprehensive quality control, value chain integration, time based management (TBM), benchmarking, outsourcing or facility management (FM), - orientation to change management: lean management (LM), business process reengineering (BPR),

- orientation to organizational forms: learning organization, intelligent organization, network organization, virtual organization, also

- in the 21st century, new management solutions are viewed as new opportunities for organizations, where new organizations are networks of virtual rather than hierarchical (vertical) integration, based on interdependence rather than independence, and on mass care for the customer rather than mass production.

It seems that one of the best methods of creating unique value is a strategy based on value innovation. Innovativeness in this context means increasing the efficiency of actions through better use of resources, whereas the method for a more efficient use of resources is becoming a value added.

In the real estate market, managing the value of real estate, i.e. saving through investments, consists in promoting savings through active management of the Facility Management area (FM) and, at the same time, taking actions aimed at increasing the value of real estate.

According to Wiliams (1996), the operational definition of the meaning and extension of the concept of FM is the mission of Facility Management, which concerns:

- quality: ensuring continuous improvement of operational requirements in the area of real estate and auxiliary services,

- value: adding and maintaining the value of real estate in the area of the actual state,

- risk: by controlling performance (e.g. safety and efficiency control), costs and readiness for innovative changes.

Management in the real estate market does not only concern the implementation of investment projects, but also concerns value management throughout the entire real estate life cycle (Czarnecki et al. 2012). Management of the real estate over its whole life and important saving of costs in real estate is possible mainly through investment decisions (Śliwiński 2012). An example of the investment concerning reduction of the costs of real estate and improving its value is investment in modern central heating equipment e.g. joining the policy of sustainable development promoted by the state. With these investments, it is possible to achieve substantial savings while increasing the value in the real estate market. Also with regard to human resources, motivating as a management strategy represents an important part of supervising work efficiency and stimulating employees to increase the efficiency (Masłyk-Musiał 2000).

In conclusion, it should be emphasized that the increase in the value of real estate as a value added is the main determinant of investment decisions in the process of management of sustainable development over the entire property life cycle.

However, the most modern strategy is (Mirski 2014) aimed at the same time at 
the maximum distinguishing on the market (differentiation aspect) and conscious integration with the market. It corresponds to the concept of the Blue Ocean strategy (Chan Kim et al. 2010). The Blue Ocean strategy postulates being based on value innovation, in which, on the one hand, the factors influencing the intensification of competition in the industry are limited and, on the other hand, the value for purchasers is increased by introducing product features that have not been offered by competitors to date.

These concepts differ in their
recommendations for company
management and implementation of
changes. According to the analysis of our
own research on the barriers and benefits
of innovation processes in the real estate
market, and modern management concepts
of the 21 st century, all of them - oriented to
the management process, change
management or organization processes -
prefer the value creation strategy as the
most promising in implementation
sustainable development, while providing a
long-term reduction of costs.

Also, all of them will minimize most of the barriers to implementation of innovations, and therefore, due to the benefits, they will determine investment decisions in the process of sustainable development management throughout the life cycle of real estate. However, it should be generally stressed that the company's management strategy for creating value is the most promising in the implementation of sustainable development while offering the long-term cost reduction.

\section{Conclusion}

Innovations are becoming increasingly important from the standpoint of the competitiveness of the economies in the global market. The study presents the identification and assessment of barriers to innovativeness in the construction sector. The hypothesis was proposed that the development of the construction sector, implemented with innovations represents a necessary component of leading the economy towards sustainable development. Analysis of empirical data and existing data on innovations in the local, national real estate market revealed that respondents perceive the benefits and barriers to innovations as key determinants of the concept of competitiveness and sustainable development of the real estate sector. With the emphasis on effective management aimed at reducing risks and increasing interest in sustainable development, it has been concluded that, by combining economic, environmental and social aspects, it promotes a higher standard of living and well-being and a reduction in harmful effects on the climate and the environment.

The analysis of barriers showed that the lack of financial resources, lack of human resources, administrative and legal problems and the biggest barrier - the dominance of substantial competitors in the market - indicate that the state of Poland's innovativeness indirectly determines the competitive position of the country and determines the distance that separates Poland from the leaders. Furthermore, the analysis of the barriers identified for both the local and national real estate market clearly shows that the barriers represent risk factors for the analyzed market.

The paper presents concepts of innovativeness in the management strategy of the 21st century enterprises. It was emphasized that the key to success is not to increase competitiveness, but to organize business activities for which competition does not yet exist, and that value creation fosters a clear reduction in costs in longer perspective. One of the best ways to create unique value is to use a strategy based on value innovation while striving for uniqueness and low costs. And it is the implementation of this strategy that generates value added in this process. Furthermore, it is the most promising strategy for achieving sustainable development while at the same time offering long-term cost reduction. 
The survey allowed for the achievement of the study aim and confirmed the validity of the assumed hypothesis.

\section{References}

1. Calantone R.J., Cavusgil S.T., Zhao Y. (2002). 'Learning orientation, firm innovation capability, and firm performance', Industrial Marketing Management, 31(6), 515-522.

2. Chan Kim, W., Mauborgne, R. (2010). Strategia błękitnego oceanu, MT Biznes, Warszawa.

3. Construction Marketing Group.World Green Building Council (2015). 'Analiza rynku zrównoważonego budownictwa. Badanie percepcji rynku'. [Retrieved July 01, 2016],

4. http://ocdn.eu/jcmsforbes / cad6c87bd04c39a2be04b16585e2232f.pdf

5. Czarnecki,L., Kaproń,M., Piasecki,M., Wall S.(2012). 'Budownictwo zrównoważone budownictwem przyszłości', Inżynieria i Budownictwo, 1.

6. Drucker, PF. (1992). Innowacje i przedsiębiorczość: praktyka i zasady.PWE.Warszawa.

7. European Innovation Scoreboard. (2017). [Retrieved May 01, 2018],

8. http://ec.europa.eu/growth/industry/i nnovation/facts-figures/scoreboards_pl.

9. European Innovation Scoreboard. (2016). [Retrieved July 02, 2017],

10.http://eu.europa.ey.growth/industry/in novation/facts-figure/scoreboards_pl.

11. Gorzen-Mitka,I; Leading markers of risk culture in organization',European Journal of Sustainable Development', 7(1), 423-434.

12.Grudzewski, WM. (2006), 'Współczesne kierunki rozwoju nauk o zarządzaniu', Ekonomika i Organizacja Przedsiębiorstwa, 3, 12-13.
13.GUS. (2013-2015, 2014-2016, 20152017). Działalność innowacyjna przedsiębiorstw w Polsce w latach od 2013 do 2017, [Retrieved September 08, 2017],

14.https://stat.gov.pl/files/gfx/portalinfor macyjny/pl/defaultaktualnosci/5496/14/ 5/1/dzialalnosc_innowacyjna_przedsiebior stw_w_polsce_w_latach_2013-2015; 20142016; 2015-2017.pdf.

15.GUS. (2007-2013). Centrum badań i Edukacji Statystycznej GUS, Raport Końcowy. Badanie Innowacji w mikroprzedsiębiorstwach. [Retrieved from:September 05.2015], 16.http://stat.gov.pl/files/gfx/portalinfor macyjny/pl/defaultstronaopisowa/5804/1 /1/raport_badanie_ 17.innowacji_w_mikroprzedsiebiorstwach. pdf.

18. Hult G.T.M., Hurley R.F., Knight G.A. (2004). 'Innovativeness: Its antecedents and impact on business performance', Industrial Marketing Management,. 33(5), 429-437.

19.Jaikumar, R., (1986). 'Post-industrial manufacturing'. Harvard Business Review, XI-XII

20.Janasz, K., Wiśniewska, J. (2017). 'Aktywność innowacyjna przedsiębiorstw w Polsce', [w:]

21.'Doskonalenie działania przedsiębiorstw i instytucji wobec przemian społeczno-gospodarczych',

22.Innowacje-Finanse-Otoczenie biznesu, ed. J. Kaczmarek, P. Krzemiński, Kraków, 17-27.

23.Jin, Z., Hewitt-Dundas, N., Thompson, NJ. (2004), 'Innovativeness and performance: evidence from manufacturing sectors', Journal of Strategic Marketing, 12, 255-264.

24.KOM. (2010) 2020). EUROPA 2020, Strategia na rzecz inteligentnego i zrównoważonego rozwoju sprzyjającego włączeniu społecznemu. KOM (2010) 2020, Bruksela,[Retrieved September 15, 2017], 25.http://ec.europa.eu/eu2020/pdf/1_PL_ ACT_part1_v1.pdf. 
26. Korombel, A.,Ławińska, O.(2018), 'Private Investments in European Union Countries-Polish Case', Proceedings of the 4th International Conference on European Integration (ICEI 2018), Ostrava, 17-18 May 2018, Czechy, 789-797.

27.Lee, SM.,Olson,DL.,Trimi,S. (2012).,'Coinnovation convergenomics, collaboration, and co-creation for organizational values', Management Decision, 5.

28.Masłyk-Musiał, E. (2000), Strategiczne zarządzanie zasobami ludzkimi, Oficyna Wydawnicza Politechniki Warszawskiej, Warszawa.

29.McKinsey\&Company, (2015), Raport: Polska 2025. Nowy motor wzrostu w Europie. [Retrieved December 22, 2017], 30.http://mckinsey.pl/publikacje/raportpolska-2025-nowy-motor-wzrostu-weuropie-2/.

31.Ministerstwo Rozwoju Regionalnego. (2011). Krajowa Strategia Rozwoju Regionalnego 2010-2020; Regiony, Miasta, Obszary Wiejskie, Monitor Polski 36(423).

32.Ministerstwo Rozwoju Regionalnego. (2012). Koncepcja Przestrzennego Zagospodarowania Kraju 2030, Monitor Polski, 3(252).

33.Mirski, A. (2014), 'trategie innowacji w zarządzaniu przedsiębiorstwem', Zeszyty Naukowe Politechniki Śląskiej, seria Organizacja i Zarządzanie, 74(1921), 557568.

34.National Cohsion Strategy. (2007-2013, 2014-2020), [Retrieved May 17, 2016], 35.https://www.google.pl/?gws_rd=ssl\#q= narodowa+strategia+sp $\%$ C3\%B3jno\%C5\% $9 \mathrm{Bci} \& *$ spf $=673$

36.

37.PAP (2017). 'Polska na szarym końcu w UE pod względem liczby mieszkań. Powinniśmy podwoić zasób mieszkaniowy', Dziennik.pl. Nieruchomości.

38.Peres,R., Muller,E., Mahajan,V.(2010), 'Innovation diffusion and new product models: A critical review and research directions', International Journal of Research in Marketing, 27(2).

39.Pomykalski, A. (2001), Zarządzanie innowacjami, PWN, Warszawa-Łódź.

40.Prystom, J. (2012), Innowacje w procesie rozwoju gospodarczego. Istota $\mathrm{i}$ uwarunkowania. Warszawa. Difin

41.Pudło, P. (2012), 'Charakterystyka barier rozwoju działalności innowacyjnej w ujęciu kapitału intelektualnego - wyniki badań', Nierówności Społeczne a Wzrost Gospodarczy, 25.

42.Schwab,K.(2017-2018), 'The Global Competitiveness Report 2017-2017', [Retrieved March 15, 2018], 43.http://www3.weforum.org/docs/GCR2 017-2018/05FullReport/TheGlobal

CompetitivenessReport 2017\%E2\%80\%932018.pdf.

44.Sipa, M. (2017), 'Innovation as a Key Factors of Small Business Competition', European Journal of Sustainable Development',.6(1), 344-356.

45.Sitek M.(2016), 'Zrównoważone budownictwo jako przejaw innowacyjności w sektorze nieruchomości' Zesz. Nauk. Wyższej Szkoły Humanitas, Zarządzanie, 17(2), 349-358

46.Sitek, M. (2018), 'Assessment of innovation and innovation risk on a local real estate market, in the context of the national market', 25th Anniversary Conference Geographic Information Systems Conference and Exhibition "GIS ODYSSEY 2018"Conference proceedings, 10 - 14 September 2018, Perugia, Italy, 435-443.

47.Skibiński, A. (2018), 'Assessment of the Degree Aging Labour Force for Example of Poland and Slovakia', European Journal of Sustainable Development, 7(3), 473-482.

48.Śliwiński, B. (2012), 'Mądre oszczędzanie czyli zarządzanie wartością nieruchomości w całym cyklu jej życia oraz redukcja kosztów obszaru Facility Management', Administrator, 2. 
49.Świtalski, W. (2005), Innowacje i konkurencyjność, Wydawnictwo Uniwersytetu Warszawskiego, Warszawa

50.Urząd Statystyczny w Katowicach, (2017), Województwo Śląskie.

Podregiony,Powiaty,Gminy. Dział VI: Infrastruktura komunalna. Mieszkania. [Retrieved March 15, 2018],

51.https://katowice.stat.gov.pl/publikacjei-foldery/roczniki-

statystyczne/wojewodztwo-slaskie-2017podregiony-powiaty-gminy,5,16.html.
52.Wiley,J.,Benefield,J.,Johnson, K.(2010),'Green Design and the Market for Commercial Office Space,' Journal of Real Estate Finance and Economics, 41(2), 228243.

53.Williams, $\quad$ B.(1996), $\quad$ Facilities Economics-Incorporating Premises Audits. Building Economic Bureau, London. 